\title{
The Conventional Status of Reflexive Awareness: What's at Stake in a Tibetan Debate?
}

Jay L. Garfield

Smith College, jgarfield@smith.edu

Follow this and additional works at: https://scholarworks.smith.edu/phi_facpubs

Part of the Philosophy Commons

\section{Recommended Citation}

Garfield, Jay L., "The Conventional Status of Reflexive Awareness: What's at Stake in a Tibetan Debate?" (2006). Philosophy: Faculty Publications, Smith College, Northampton, MA.

https://scholarworks.smith.edu/phi_facpubs/18 


\section{UNIVERSITY of \\ HAWAI'I \\ PRESS}

The Conventional Status of Reflexive Awareness: What's at Stake in a Tibetan Debate? Author(s): Jay L. Garfield

Source: Philosophy East and West, Vol. 56, No. 2 (Apr., 2006), pp. 201-228

Published by: University of Hawai'i Press

Stable URL: https://www.jstor.org/stable/4488015

Accessed: 03-08-2018 14:24 UTC

JSTOR is a not-for-profit service that helps scholars, researchers, and students discover, use, and build upon a wide range of content in a trusted digital archive. We use information technology and tools to increase productivity and facilitate new forms of scholarship. For more information about JSTOR, please contact support@jstor.org.

Your use of the JSTOR archive indicates your acceptance of the Terms \& Conditions of Use, available at https://about.jstor.org/terms

University of Hawai'i Press is collaborating with JSTOR to digitize, preserve and extend access to Philosophy East and West 


\section{THE CONVENTIONAL STATUS OF REFLEXIVE \\ AWARENESS: WHAT'S AT STAKE IN A TIBETAN DEBATE?}

\section{Jay L. Garfield}

Department of Philosophy, Smith College

\section{The Issue between Tsong khapa and Mipham}

Ju Mipham Rinpoche (1846-1912), an important figure in the Ris med, or nonsectarian, movement influential in Tibet in the late nineteenth and early twentieth centuries, was an unusual scholar in that he was a prominent Nyingma scholar and rDzog chen practitioner with a solid dGe lugs education. He took dGe lugs scholars like Tsong khapa and his followers seriously and appreciated their arguments and positions, but he also sometimes took issue with them directly. In his commentary on Candrakìrti's Madhyamakāvatāra, Mipham argues that Tsong khapa is wrong to take Candrakirti's rejection of the reflexive character of consciousness to be a rejection of the conventional existence of reflexive awareness. Instead, he argues, Candrakirti only intends to reject the reflexivity of awareness ultimately, and, indeed, Mipham argues, it is simply obvious that, conventionally, consciousness is reflexive.

The debate is interesting for a number of reasons. First, it focuses attention on the hermeneutical strategies of Tsong khapa and his student rGyal tshab, as the case that they build against the conventional existence of reflexive awareness is philosophically complex, but grounded in a reading of a very few verses from the Madhyamakāvatāra and Saantideva's Bodhicāryāvatāra. Second, it forces us to confront a delicate question that Mipham poses: what is so important about the conventional existence of reflexive awareness that it makes a philosophical difference whether or not consciousness is reflexive? Third, it opens a window onto dGe lugs pa doxography, and in particular their account of the relationship between the accounts of the states of mind of Cittamātra, Svātantrika-Madhyamaka and Prāsangika-Madhyamaka. Fourth, and perhaps most interestingly, it raises deep questions about the differences in epistemological perspective between Mipham and Tsong khapa and shows just how revolutionary Tsong khapa's thought was.

Attention was drawn to this debate by Paul Williams in an article (1983) and more recently in his much more extensive book (1998), and it is indeed Williams' careful treatment of this question, its textual basis in the Indian loci classici, namely Madhyamakāvatāra VI:72-78 and Bodhicāryāvatāra IX:17-25, that sparked my interest in this debate. Williams points out that it is not at all obvious why Tsong khapa and rGyal tshab are so insistent on the conventional nonexistence of reflexive awareness, beyond its obvious ultimate nonexistence, and ends up defending Mipham's plausible argument for the claims that Candrakirti and Śāntideva countenance the conventional reality of reflexive awareness and that they are correct to do so. 
The more I thought about this debate and the closer I looked at the texts, the more I became convinced of three things: (1) that Tsong khapa and rGyal tshab are dead right and that Mipham and Williams are dead wrong (both hermeneutically and philosophically); (2) that Mipham is very smart and that it pays to figure out why somebody that smart got something wrong; and (3) that most of those who have looked at this debate, or who have taken Tsong khapa's position for granted, for that matter, have missed what is at stake. What is at stake is of the first philosophical importance, both within the framework of Madhyamaka philosophy and for the philosophy of mind more generally.

I will argue that Tsong khapa has correctly understood the thesis that Candrakīti and Śāntideva have defended, namely that not only are all of the arguments for even the conventional existence of reflexive awareness unsound but that their conclusion is false: reflexive awareness has no place in conventional reality and is indeed incoherent. Reflexive awareness, according to this view, involves a commitment to a view that intentionality is an intrinsic rather than a relational aspect of cognition; to a view that we have a special kind of immediate, nondeceptive access to our own minds and to their states; and to the view that we specify an essence of the mental. All of these theses are inconsistent with Prāsanigika-Madhyamaka-both as it is articulated in the Indian texts so classified by Tibetan doxographers and according to the tenets ascribed to that school by those doxographers-and all are false. ${ }^{1}$

\section{A Close Look at the Two Principal Indian Texts}

Let us begin by examining the principal Indian texts at issue, as the Tibetan debate is pitched at first as hermeneutic and is grounded in readings of the Madhyamakāvatāra and the Bodhicāryāvatāra. We begin with Candrakīrti's Madhyamakāvatāra and its autocommentary. Initially, I will pay consideration only to the Indian text itself, without regard to Tsong khapa's or Mipham's commentaries. The discussion, in the context of Candrakirti's attack on Cittamātra in the sixth chapter, begins with a consideration of the second, and in important respects most fundamental, of the three Cittamātra natures - the other-dependent. The other-dependent nature of phenomena, or aspect of reality, is the fact that phenomena are all dependent on, or are aspects of, mind, and have no independent, extra-mental existence. For Cittamātra theorists, such as Vasubandhu, to whom Candrakirti is probably principally replying, the other-dependent is truly existent, rather than merely conventionally existent and, in its aspect as truly existent, is nondual; that is, the other-dependent nature of objects is that they are non-different from mind. Candrakirti begins the argument by pointing out that if there is no subject-object duality in the other-dependent, then from the perspective of one apprehending reality there would be no awareness of it, since the very structure of subjectivity is dualistic:

72

If without either subject or object,

The other-dependent existed empty of duality 
Then by what would its existence be known?

It makes no sense for it to exist unapprehended.

If the other-dependent were empty of both subject and object, by what would its existence, or your awareness of it, be perceived? It is not tenable that it is aware of itself, because this would involve the inconsistency of reflexive action. In the same way, the blade of a sword cannot cut itself; nor can a finger touch itself. ... (Mipham 2002, p. 155)

Candrakīrti hence sets up a dilemma: for a state of consciousness apprehending the other-dependent to constitute genuine knowledge, one must be aware of it. Such a state must be perceived either by another state of consciousness or by itself:

Moreover, it cannot be apprehended by another state of consciousness, because you would contradict your own position. This is because if another state of consciousness were the object of a state of consciousness, then you would give up your entire position regarding consciousness. Therefore, it is not apprehended in any of these ways. That which is not apprehended is not existent. (pp. 155-156)

If it is perceived by another, we have given up the claim that is at the heart of the idea of the nondual apprehension of the other-dependent-the idea that there is no distinction between subject and object in moments of consciousness that apprehend the true nature of reality-for now we need a subjective state of consciousness distinct from the one that is its object in order for it to be experienced. ${ }^{2}$ It is in this context, Candrakīrti imagines, that the Cittamātra proponent is driven to propose reflexive awareness as providing an account of how a state of apprehension can nondually - that is, immediately - apprehend an object of knowledge, namely itself:

Here one might say, "Even if it is not apprehended by another, nonetheless reflexive awareness exists. Therefore, since there is reflexive awareness, it is apprehended." (p. 157)

Candrakirti will have none of this:

But even this is not the case, as it is explained:

73

It is not proven that it is experienced by itself.

The statement that it apprehends itself is not proven.... (p. 158)

That is, there is no prima facie evidence for this claim. But there is a philosophical argument common to the Cittamātra tradition that is meant to establish, independently, the existence of reflexive awareness, the so-called "memory argument":

Suppose one argued as follows: One has to maintain that there is reflexive awareness, because otherwise, when at a later time, I say, "I saw ..." and remember the remembered object, and when I think, "I saw," there could not be a memory of the awareness of the object of that thought. (p. 156)

Here is how this goes: When I tell you now that I remember a blue pot that I saw yesterday, I don't simply remember the blue pot, I remember seeing the blue pot. 
That is, I remember a mental state as a state of awareness. But I also remember the content of that perception, namely the blue pot. However, there was only a single perceptual state, and so that state must have been simultaneously a perception of a blue pot and an awareness of the fact of the perception of a blue pot-that is, an awareness that was reflexive in character. Otherwise, there would be no basis for my current memory. While I might once have seen a blue pot, if I had not been simultaneously aware of that, there would have been nothing to recall:

If what is remembered were the experiencing subject, then since even consciousness would not have been experienced, there would be no memory! (p. 156)

Moreover, the proponent of reflexivity continues, to deny this would be to accept an infinite regress. Obviously, we are aware of our own states of awareness, but ...

It is even irrational that consciousness is experienced by another moment of consciousness, because if one said that another conscious state must experience a conscious state, a vicious infinite regress would arise. (p. 157)

Candrakirti rejects this argument as question-begging:

$73 b-d$

If one were to prove it through memory of a prior time,

You would be attempting to prove it through an unproven premise;

An unproven premise can't prove anything.

That is, he will argue, the memory argument relies on the premise that the current memory of my consciousness at a previous time must be the memory of my being conscious of an object, rather than simply the memory of that of which I was conscious. But there is no such requirement on memory:

How could it be that through a memory that is always impossible, through an unproven memory, one proves the existence of an unproven reflexive awareness? Though it exists through the power of mundane convention, even from that perspective, it is impossible for reflexive awareness to be the cause of memory. (p. 158)

Moreover, the argument presupposes that there is only one plausible account of memory, namely reflexive awareness. But for that premise to be established, it would first have to be established that reflexive awareness is ever a cause of memory and that there is no other plausible cause-and that has not been established:

Why is this? Suppose that here, just like fire, one argued for the existence of reflexive awareness from the presence of consciousness. If that were the case, just as after smoke, one sees fire, when memory arises at a later time, one would have to ascertain it. So, even though that reflexive awareness would be necessary, since it is not established, how could there be memory caused by reflexive awareness, or that would not arise without reflexive awareness? In the same way, it does not follow merely from seeing water that there is a water-producing gem, or from merely seeing fire that there is a fireproducing gem; for they can be produced without them: from things such as rain, or rubbing sticks together. In the same way, without reflexive awareness, one can explain the occurrence of memory. (pp. 158-159) 
So the posit of reflexive awareness is a gratuitous posit. Candrakīrti also points out that it is a gratuitous philosophical posit, and not a mere report of mundane conventions. That is, it is far from common sense to explain memory in terms of reflexive awareness:

\section{4}

However, according to us, this memory is no different from

That by means of which the object was apprehended.

Therefore, the memory occurs in the form "I saw...."

This is also the way it goes in mundane convention.

Candrakirti now turns to the question of what hangs on this for Yogācāra. What is at stake is the other-dependent nature, and in particular its nondual, ultimately existent status. It is a central tenet of the idealist Yogācāra system that while external phenomena are unreal, and so have a purely imaginary nature, the mental episodes whose deceptive structure consists in taking them as objects do exist, and so the reality of these phenomena qua hallucinations - that is, their dependent nature-is the foundation of Yogācāra metaphysics. In fact, they take the consummate nature of things, the nature whose apprehension is soteriologically efficacious and epistemologically veridical, precisely to be the fact that the dependent-the mental episode-is empty of the imagined, namely its external object.

But, Candrakirti argues, this poses both a serious epistemological problem and a serious problem in the metaphysics of mind, for these intentional states must be knowable. For one thing, Buddhist metaphysicians are in agreement that the categories of real entity and object of knowledge are necessarily coextensive. Knowledge can only be of the real, and anything real is knowable. But Yogācāra cannot consistently assert that they are known by other mental states, since they would then, from the perspective of the states that apprehend them, be imaginary. The only way in which they could be known as they are, then, is reflexively. So, without the reflexivity of awareness, Candrakīrti concludes, Yogācāra cannot consistently maintain the knowability, and hence the reality, of the states whose reality is fundamental to their entire system:

75

Since it follows that there is no reflexive awareness,

Who will apprehend your other-dependent?

Since agent, action and object cannot be identical,

It is irrational to say that it can be aware of itself.

That is, Candrakīrti argues, not only is the reflexivity of awareness gratuitous when it is posited to explain such things as memory, but it is incoherent, by virtue of the identity of the agent, action, and object that would be required. Now, this grammatical argument may in the end beg the question against the proponent of the reflexivity of awareness. On the other hand, it is important to note as an exegetical matter that Candrakīrti is arguing that from an ordinary standpoint-as well as from the standpoint of Sanskrit grammar-when we think of the structure of intentional 
action, we distinguish agent, object, and action as three different relata. Candrakīti then draws the explicit moral that if one takes the other-dependent to exist as an unknowable, one has left the realm of rational debate: one is now positing a mystery in order to explain reality, and is giving up the very possibility of argument by reductio, since any absurd consequence could be taken simply to be the true assertion of the reality of another mysterious unknowable. And finally, since the otherdependent is the ontological foundation of conventional reality, if this is incoherent, the Yogācāra understanding of ordinary experience collapses:

76

If one maintained that unarisen and uncognised,

An other-dependent entity existed inherently,

Since this would be completely irrational,

What could be undermined by the son of a barren woman?

77

If the other-dependent doesn't exist even the slightest bit,

How could the conventional come to be?

By adhering to substance, as per others' views,

One would obliterate the entire framework of the everyday world.

We will have to ask whether this rejection of reflexivity is intended to apply merely at the ultimate level or also at the conventional, and we will turn to this question later; but now we turn to the second of the two texts regarded by Tibetan exegetes as representative of the Prāsanigika school that discusses reflexive awareness: Śāntideva's Bodhicaryāvatāra, chapter IX. Because of the obscurity of these passages we will consider it in the context of rGyal tshab's commentary, though we will try not to prejudge the philosophical and hermeneutical issues that will concern us below. Like Candrakīrti, Śantideva considers the issue of the reflexivity of awareness in the context of a refutation of Yogācāra. He begins by noting the principal motivation for this idealistic doctrine: the view that if we are to make sense of a projected conventional world, we must posit an independently real mind that projects it:

17

Yogācāra:

If the mind itself is an illusion,

In that case, what is perceived by what?

Śāntideva has the Mādhyamika respond that positing a self-cognizing mind as the subject of all experience would be no solution to this conundrum, by virtue of the incoherence of reflexive action:

Mādhyamika:

But the protector of the world has also said

That the mind does not perceive itself.

Just as the blade of a sword cannot cut itself,

So it is with respect to the mind. 
The imagined Yogācāra interlocutor responds that there is an example of reflexive action, namely the flame of the lamp that illuminates itself as well as others, just as consciousness is regarded as presenting itself as well as others:

18

Yogācāra:

It does so, just as the flame of a lamp

Completely illuminates its own existence.

But, the Mādhyamika replies, obscurely:

\section{Mādhyamika:}

The flame of the lamp is not illuminated, because

It is not concealed by darkness.

Now, this is, to be sure, dark stuff. Let us turn to rGyal tshab's commentary for help:

rGyal tshab:

... This example doesn't establish anything: the flame of the lamp is not illuminated by itself, because the flame of the lamp does not have the activity of self-illumination. This is because since it has no need to illuminate itself, it is not able to. In the same way, it is irrational to say that darkness obscures both itself and others because it would follow that darkness was obscured by darkness, and it isn't. If it were obscured, then when one needed a pot obscured by darkness, one would not see the darkness, either! (pp. 396397)

While we might imagine that rGyal tshab is illuminating Sāntideva's prose, his commentary certainly provides yet another example of that which is not selfilluminating! Let us try to unpack the argument a bit. It seems at first like a terrible argument: since darkness doesn't conceal itself, a lamp can't reveal itself. This would be a howling non sequitur, and it would be uncharitable to take the argument to be that bad if we have an alternative reading at our disposal, and there is a better reading. rGyal tshab's point is that the sense in which the lamp illuminates itself is the wrong sense to do the proponent of reflexive awareness any good: while the lamp may indeed shed light on itself, it makes itself aware not to itself but rather to a perceiver who is other than it, and so that does not indicate any intrinsic capacity of the lamp to be revealed and to be that to which it is revealed.

If these capacities were intrinsic to such things through the analogy of darkness, rGyal tshab emphasizes, then concealing should be intrinsic to darkness, and hence when one sees darkness one should not even see the darkness. For the argument to make sense, the relativity to a perceiving subject must be supplied. That is, darkness conceals another object for a subject. The metaphor of illumination only makes sense as an account of reflexivity in the context of an account of mind if we consider the subject for whom the flame of the lamp is illuminated. The proponent of reflexivity argues not simply that consciousness is an object for itself, but necessarily that it is also the subject, and moreover that its power of awareness is intrinsic to it and so makes it aware of itself. But all that the example shows is that the lamp can make 
another know it, and hence that it has an extrinsic illuminating power. The language of act-object-action in the presentation obscures the fact that the nature of subjectivity is what is at issue, and so the relevance of the example to the case at hand is crucial. ${ }^{3}$

The yogacārin replies with yet another example meant to demonstrate the fact that some subjective properties may be extrinsic and others intrinsic. A clear crystal may take on a blue appearance when we put it against a blue background, and so may depend on its "object" for its blueness; nonetheless, the blue object does not depend on anything else to be blue. Lurking behind this example is another stock example used in defense of the reflexivity of awareness: while the crystal may be derivatively blue, it is intrinsically clear, and its clarity is what allows it to take on the colors of those things around it. Similarly, one might argue, while an intentional state may be extrinsically of a blue pot, it is intrinsically intentional, and its intrinsic intentionality is what allows it to be aware of other objects. But if it is intrinsically intentional then it would be intentional even in the absence of an object, and it could then only be directed upon itself. Hence, this stock Yogācāra argument goes, any state of consciousness aware of something else must simultaneously be an awareness of that awareness; otherwise, one could be aware but not aware that one is not aware, which would be absurd, just like the case of a crystal that reflected blue but which was not simultaneously clear:

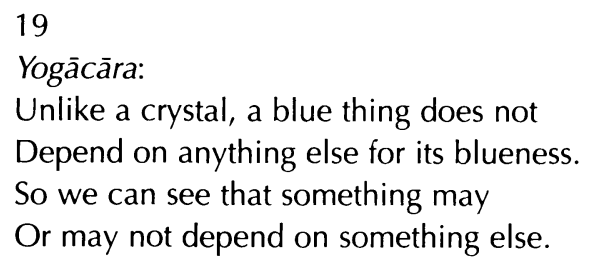

The mādhyamika responds that it is simply erroneous to assert that blue things are intrinsically blue. Their blueness depends on external causes and conditions (such as paintbrushes, ambient light, our perceptual systems, etc.). The example thus begs the question:

20

Mādhyamika:

In the absence of blueness,

A thing cannot make itself blue all by itself.

Śantideva then returns to the flame-of-the-lamp analogy, arguing that it is inadequate to demonstrate the possibility of reflexive awareness:

21

Since when it is said that the flame of the lamp illuminates,

It is asserted that this is known through awareness,

When it is said that the mind illuminates,

By means of what does one know this? 
As rGyal tshab notes, following Prajñākaramati, the argument goes roughly like this: if you needed another flame to see a first flame, you'd be stuck with an infinite regress and a huge butter bill. Similarly, when we are conscious of a perceptual object, if, in order to be conscious of the fact that we are conscious, we needed another intentional state directed at the first, we would be off on an infinite regress of intentional states. But this doesn't get us to the reflexivity of awareness, for even if we grant that a flame illuminates itself, it illuminates itself for a perceiver, and the presence of that subjective perceiver who is different from the flame is built into the example. If we were to posit the same structure in the case of the mind, we'd be off on the same regress. But when the Yogācāra philosopher defends the reflexivity of awareness, he must argue that the illumination of the mind by itself is also for itself, and the lamp, even on his own understanding of the case, is not an example with the requisite structure:

\section{rGyal tshab:}

You say that even if the flame of the lamp is not illuminated by itself, the flame of the lamp must be illuminated. So it is said that consciousness must be conscious of itself. So, you say, even if consciousness does not illuminate itself, it must be said that the mind is illuminated. But it is irrational to say that consciousness is essentially the object of another consciousness. If it were essentially the object of another consciousness there would be a vicious infinite regress. So, if it is irrational for it to be self-conscious, it is equally irrational for another to be conscious of it. (p. 398)

\section{Prajñākaramati:}

Even if the flame of the lamp completely illuminates itself, this example does not establish the reflexivity or awareness in the case of the mind. When one says-that is, revealsthat the flame of the lamp illuminates - that is, illuminates itself without depending on another flame-one has cognized that, since the flame of the lamp is an object of knowledge. One says that the mind "illuminates," but by virtue of what cognitive episode can one say that? (p. 45)

\section{Śāntideva concludes:}

\section{2}

Since, whether the mind illuminates or not,

Nothing perceives it,

There is no point in discussing it,

Just like the charms of a barren woman's daughter.

Śāntideva hence draws all of these arguments together in a rejection of the metaphor of illumination as inapposite to the relationship between the mind and its mental states, and so he concludes that it fails to fend off, and indeed induces, a regress - a regress that there is no reason even to suspect in the absence of this metaphor. While the flame of the lamp acts on things to illuminate them for another, a mental episode is only the subject of its intentional object. There is no reason to think that it, or any other mental state, observes it acting on its object. There is hence no vicious infinite regress of subjectivity: a mental episode may constitute an instance of awareness for a subject without any awareness being directed on it, even 
its own. This point will be of importance when we consider the debate between Tsong khapa and Mipham.

Sāntideva then anticipates the memory argument familiar from Candrakīrti:

23

Yogācāra:

If there is no reflexive awareness,

How could a state of consciousness be remembered?

rGyal tshab:

Suppose one argued as follows: If there is no reflexive awareness, how could there be a memory of a subjective state of consciousness? Since there couldn't be, how could one infer that there was experience through the evidence of memory, as when I say, "I saw blue earlier?" ... When I say, "I saw ...," through reasoning on the ground of subjective memory one establishes the existence of a subjective experience. That subjective experience is reflexively aware. By arguing through the refutation of the regress ensuing from another being aware of it, reflexive awareness is established. (pp. 398-399)

Śāntideva presents a fanciful analogy to explain the nature of memory in the absence of reflexive awareness. A bear is hibernating and is bitten by a rat. He develops an infection at the site of the wound. When he awakes in the spring he experiences the pain of the infected wound and knows on that basis that he experienced a rat bite, even though at the time he was not aware that he was experiencing the bite. The point is that (1) one can be the object of an occurrence the effect of which is that one is aware of its causal sequellae later; and (2) those sequellae can induce a cognitive state directed at the earlier occurrence even if (3) one was not aware of that occurrence at the time. It hence follows that one can develop a cognitive state directed at a past perceptual episode even if one was not also aware that one was perceiving at the time of that perceptual episode:

Mādhyamika:

By virtue of a connection to having experienced something else, Just like the poison of a rat.

rGyal tshab:

Reflexive awareness is not proven by subjective experience. When, through the apprehension of blue, another blue object is experienced, as when I say, "previously, I saw this blue object," that object is without a subject. This is because, through a memory that is without one [a subject], the memory of a subjective experience can arise. However, through the experience of a subject one doesn't, just as when a poisoned rat bite is not experienced there is still a later memory of it....

The rat's bite is just like the experience of the blue object. The fact that while the bite occurs at the first moment, the poison that remains is like the current existence of the experiencing subject, though the object was apprehended at the first moment. Thus the fact that the subject does not experience itself is like the fact that the poisoned bite was not experienced. The later memory of the bite is like the memory of the object. The fact that although through the very memory of the experienced object, the previous subject did not experience itself, it still remembers is like the fact that by virtue of the very memory of the bite there is the memory of the poison that was not experienced. ${ }^{4}$ (p. 399) 
We thus see in the Madhyamakāvatāra and the Bodhicāryāvatāra a systematic consideration and rejection of a range of arguments for the reflexivity of awareness, including arguments based on its necessity for memory, its necessity for the integration of experience, and its necessity in order to make sense of the relation of transcendental subjectivity to the empirical world. We also see a range of arguments against the very consistency and coherence of the concept of reflexive awareness. Both of these are, according to Tibetan doxography, Prāsangika texts, and both refutations occur in the context of attacks on the Yogācāra school. Let us now turn to a third Madhyamaka text relevant to this debate, not only the only other major Indian Madhyamaka text to take on this topic but the only one regarded by Tibetan exegetes as a Svātantrika text. Here we will encounter a defense of reflexivity, but a defense importantly qualified. Consideration of that qualification will enable us to understand better the ensuing Tibetan debate.

\section{A Third Relevant Text: Śāntarakṣita's Madhyamakālaṃkāra}

Let us now work through the relevant verses of Śāntarakṣita's Madhyamakālaṃkāra and relevant portions of its autocommentary. Śāntarakșita approaches the issue from a very different perspective. He begins by arguing that the very distinction between the sentient and the insentient is marked by the presence or absence of selfconsciousness. Rocks are not aware of themselves; people are.

16

Consciousness arises as diametrically opposed

In nature to insentient matter.

Its nature as non-insentient

Just is the reflexivity of its awareness.

It is regarded as essentially reflexively aware-that is, as being essentially selfilluminating because it is diametrically opposed in nature to things that lack consciousness such as chunks of wood.... (Ichigo 1985, p. 70)

It is interesting to note two things about this move. First, Śāntarakșita simply takes it as obvious that there is a clear distinction between these two classes of entities, and that this distinction is to be marked in ordinary discourse (there is no high metaphysics of ultimate reality at play here) by a set of necessary and sufficient conditions. Second, Saantarakșita takes it as obvious that the relevant condition is selfawareness, something that we can see that we, as prime examples of the sentient, possess, and the absence of which renders something insentient. But Śāntarakșita is aware of the difficulties his colleagues have raised for this posit, in particular the worries about action, agent, and object identity:

17

Since it makes no sense for that which is unitary and partless

To have a threefold nature,

The reflexivity of awareness

Does not have an agent-action structure. 
Sāntaraksita's proposed solution is brutally simple, if not obviously coherent: he just denies that there is any identity of agent, object, and act in reflexive awareness, since these three components are not present. Saantarakșita is hence denying that consciousness should be understood as an action, and so as subject to the tripartite analysis of actions into agent, action, and object. Reflexivity, in his view, is simply a primitive intrinsic fact about intentionality that amounts to its not having the same action-theoretic structure as other phenomena:

18

Therefore, since this is the nature of consciousness,

It makes sense that it can cognize itself.

But since external objects have a different nature,

How could it cognize them?

We now encounter Śāntarakṣita's flirtation with Yogācāra ideas, in particular his denial of our direct cognitive access to the external world, a doctrine that earns him the curious doxographic category yogācāra-svātantrika-madhyamaka. ${ }^{5}$ In fact, he defends a representationalism curiously Cartesian in character: since a state of consciousness is immaterial and cognitive in nature, its immediate content must also be, as there is no way that a material, noncognitive thing could literally be internal to an immaterial cognitive thing:

19

If, as you maintain, consciousness

And the object of consciousness were different,

Since something different would lack its nature,

How could cognition cognize something different?

If the object had a completely different nature from that of consciousness, in that case, since the object would be completely different, perception would be impossible. Therefore, since the object of consciousness and consciousness must be one, the position that external objects are perceived makes no sense. (p. 76)

20

Although according to the representational theory of knowledge, The two are different entities,

Since it is just like a reflection,

It can be experienced merely as a designation.

\section{1}

However, according to those who reject

The representational theory of knowledge,

There cannot even be representational knowledge

Of an external world.

We have here a new argument for reflexivity: since the immediate objects of intentional states are in fact internal to those states (dare we say objectively inexistent?), every conscious state, just by virtue of being directed toward its immediate object, is, ipso facto, directed toward an aspect of itself. Awareness that is not reflexive is, 
according to this view, a contradiction in adjecto, and this, Śāntarakṣita takes it, is a direct consequence of representationalism, which in turn is a direct consequence of the distinction between the sentient and the insentient. ${ }^{6}$

But, unlike his pure Yogācāra predecessors, like those attacked so trenchantly by Candrakīrti and Śāntideva, Śāntarakṣita does not argue that reflexive awareness exists ultimately, because he doesn't think that the mind is ultimately existent. He hence argues that it is a conventional distinguishing characteristic of the mental. This will be important when we turn to the Tibetan doxographic, exegetical, and philosophical debates below. ${ }^{7}$

63

Therefore, all entities are to be grasped

Only as characterized conventionally.

His autocommentary makes it clear that this applies to the reflexivity of awareness as well. In his fine study of Śāntarakșita's text and its commentaries, Blumenthal (2004) argues that there are two primary motivations for reflexive awareness and three standard dGe lugs arguments against it. The two motivations he cites are: (1) self-illumination on the lamp analogy and (2) the memory argument. I have argued that this underestimates the manifold motivations, which include as well the perceived need for an ontological foundation for conventional illusion and a particular formulation of representationalism.

According to Blumenthal, the three principal dGe lugs arguments against it are: (1) an infinite regress argument (which he maintains is in fact successful against Yogācāra, but not against Śāntarakṣita); (2) the refutation of the memory argument; and (3) the argument that reflexive awareness amounts to the self-establishment of cognitive states, and that self-establishment is tantamount to inherent existence (pp. 222-227). We will consider this account of the dGe lugs response below. But first, let us ask why Tibetan philosophers such as Mipham argue that the Indian sources support the view that, conventionally, awareness is reflexive, and why they think that this is in fact the correct position. We will then consider Tsong khapa's position in detail to determine whether this view is correct, both exegetically and philosophically.

\section{Why Mipham Thinks Reflexive Awareness Exists Conventionally}

Mipham argues that from the point of view of Prāsangika-Madhyamaka (and hence from the point of view of Candrakìrti and Śāntideva) reflexive awareness exists conventionally, even though it does not exist ultimately. He also argues that this position is correct. Williams $(1983,1998)$ argues that he is correct in these views and that Mipham's principal target, Tsong khapa, is wrong to attribute any concern with the conventional status of reflexive awareness to these Indian writers, and that he is wrong to reject the conventional status of reflexive awareness. Much of Mipham's discussion occurs in the context of his commentary on Madhyamakāvatāra, to which we now turn. ${ }^{8}$ 
Now, since consciousness does, as a matter of fact, experience both its object and itself, there is of course such a thing as reflexive awareness. But even if we do concede this, it is still incorrect (for the Cittamātra) to say that the subsequent memory remembers both the past moment of consciousness and the cognized object. For according to the Cittamātra, the past experience and the present recollection are different, inherently existent entities. (Mipham 2002, p. 247)

Mipham takes the reflexivity of consciousness for granted as a simple datum of conventional introspective experience. So he must read Candrakīti not as denying the reality of reflexivity in ordinary experience when he says that "this memory is no different from that by means of which the object was apprehended." Instead, he argues that Candrakirti is merely pointing out that the Cittamātra is not entitled to any conceptual link between past and future experience by virtue of their regarding mental episodes each as inherently existent, and so independent of one another. In his view, then, reflexivity simply plays no role in the argument at this stage, and so there is no reason for Candrakirti to reject it.

Let us now consider Mipham's discussion of $\mathrm{VI}: 75$. Here, of course, Mipham must contend with Candrakīrti's explicit claim that "there is no reflexive awareness" and that "it is irrational to say that it can be aware of itself." He writes:

The next question is whether the Prāsangika tradition ascribes a conventional existence to reflexive awareness and the ālaya-vijñanna. When discussing conventional reality, the Prāsanigikas do not, as a matter of fact, employ such terms, with the result that they do not affirm their existence. This is not necessarily to deny the conventional existence of reflexive awareness and the ālaya-vijñanna, for if they were nonexistent, then, like permanent sound, they would inevitably be disproved in the course of conventional analysis. The Prāsangika accept, simply on the strength of experience, that the mind is what it knows. It is like a lamp shedding light and a sword cutting. In knowing its object, the mind is selfknowing.... It is indeed well-established that in order for it to be seen, the lamplight does not need something else to illuminate it. On the other hand, it is not (inherently) self-illuminating because the darkness does not darken it. To say that the mind is selfknowing in this sense is like saying that darkness is self-obscuring or that a sword is self-cutting. All this refers to analysis directed at the ultimate status of things. But when it comes to the reflexive awareness as a conventional label, the Prāsangikas do not of course refute it. Indeed it would be impossible to do so. There is no need to object to what is just a name corresponding to the facts of experience! (p. 248)

In this remarkable discussion Mipham makes several points: (1) In his view, Prāsangika analysis is always silent about conventional reality-that is, how things are in ordinary life is simply no business of the philosopher. Therefore, no philosophical analysis could ever refute the reflexivity of awareness. Candrakirti, therefore, can only be concerned with its ultimate existence. Moreover, he asserts, conventional analysis-ordinary inquiry into how the world goes-confirms reflexivity. In the same (large) breath, however, (2) he draws on the lamp analogy to defend the empirical reality of reflexive awareness, and indeed in terms very much like those of Candrakīrti's and Śāntideva's hypothetical Cittamātra opponent: just as the lamp 
needs nothing else to illuminate itself, no mental episode needs anything else by means of which to be aware of itself. However, (3) he urges that this claim does not run afoul of the rebuttal in terms of the self-occlusion of darkness or the selfcutting by swords, precisely because he is urging only a conventional reflexive awareness. We will return to appraise these claims later.

Mipham's defense of the reflexivity of awareness and of the Indian Prāsanigika credentials of this doctrine continues in his commentary on the Bodhicāryāvatāra. In that text he offers four arguments, each, in appropriate Prāsanigika fashion, a reductio, in favor of the conventional reflexivity of awareness. Paul Williams, who endorses each of these arguments, presents them as follows:

1. "To negate svasamvedana understood in this sense would necessarily be to hold that one's mind is a hidden object for oneself (de bkag na rang blo rang la lkog tu gyur par khas len dgos pas)..." Thus what Mipham is saying here is that if one's own consciousness at time $t$ is not itself also known by oneself directly in the experience of objects at time $t$ (i.e. reflexivity), then it would have to be known by some subsequent means, such as inference, which is absurd. (Williams 1998, p. 92)

2. "Because of (1) 'it would follow that there would be no distinction in the manner of determination by consciousness of the minds of oneself and another' (rang gzhan gyi blo shes pas gcod tshul la khyad med du thal ba)." It seems at least prima facie obvious (pace Gilbert Ryle) that one should have privileged access to one's own mind, yet if consciousness lacks reflexivity and becomes a hidden object for oneself it is difficult to see how privileged access can be sustained, and likewise any difference between the modes of presentation to oneself of one's own mind and that of another. (pp. 94-95)

3. "Moreover, proving that there exists a mind in one's own continuum would be unreasonable (dang rang rgyud la blo yod pa'i sgrub byed mi rigs pa)." If one's own mind is a hidden object for oneself and therefore known on the same basis as one knows the minds of others, then how would it be possible ever to prove to oneself that one has a mind? In fact the problem of knowing one's own mind would be the same as the problem of knowing other minds. (p. 95)

4. "Eventually, the transactional conventions of awareness of referents would also be annihilated (mthar don rig gi tha snyad kyang rgyun chad par 'gyur ba sogs)." Obviously if one could not know one's own mind then there could be no conscious awareness of cognitive referents. (p. 95)

These arguments are significant. They indicate with the greatest clarity just what is at stake in this debate, and why the critique of reflexive awareness is so central to the Prāsangika account of self-knowledge. They also indicate why these arguments are not of purely historical interest. The issues at stake are immediately familiar to anyone who has followed debates about self-knowledge in the West from Descartes to yesterday afternoon. Mipham is worried that to deny the reflexivity of awareness would be to deny the immediacy of self-knowledge, privileged access, the certainty of one's own existence as a mind, and the possibility even of mediated knowledge, since one would not know anything as one's own representation.

As we shall also see, Tsong khapa agrees that this is precisely what is at stake, and, as we shall see, Tsong khapa agrees that the denial of the reflexivity of aware- 
ness conventionally undermines these tenets. The only differences between Mipham and Tsong khapa, then, concern whether these theses are true, and whether a Prāsañgika like Candrakīrti or Śāntideva endorses them or not. When we set this quartet of concerns in the context of Śāntarakșita's concern for the discovery of a distinguishing feature of the mental, we will also see that there is a doxographic dispute: whereas Mipham follows most Tibetan commentators, including all dGe lugs commentators of whom I am aware, in taking on the target of Tsong khapa's attack on the conventional existence of reflexive awareness as aimed at Cittamātra, by virtue of the context in which the discussion occurs, the real target is not Cittamātra idealism but the Svātantrika thought that phenomena conventionally have distinguishing necessary and sufficient conditions, what Tsong khapa refers to as the doctrine that, conventionally, things exist through their own characteristics.

Paul Williams, in his detailed study of the dispute between Mipham and Tsong khapa (1998) accepts the claim that the target of the attack is Cittamātra, and notes correctly that if that is the intended target, the argument is gratuitous:

The Prāsangika do not refute the conventional existence of rang rig, and only negate its ultimate existence, as this is needed for Cittamātra. It is not like permanent sound or a creator god, which can be shown not to exist by reasoning-they are not empirical possibilities.... ${ }^{9}$

Mipham, on the other hand, considers it patently obvious that reflexivity is an empirical possibility which not only is not refuted by a valid cognizer which examines the conventional, but also has compelling supporting arguments. (Williams 1998, pp. 121-124)

On the other hand, in defending Mipham, he immediately offers what can only be understood, from Tsong khapa's point of view, as a Svātantrika argument for the reality of reflexivity:

Consciousness is the very opposite of insentience, and this means reflexivity.... In light of this, Mipham wants to make it clear that when we speak of self-awareness we do not mean that in addition to an awareness of, say, the table, there is also a further cognitive act directed toward oneself. It is not necessary that in addition to an awareness of the table there is also produced another new action by oneself directed towards oneself.... Svasamvedana is the quality of consciousness qua consciousness. If there is an act of awareness then in its very being as awareness it is also self-aware. (p. 132)

This passage is revealing indeed. Williams accurately captures Mipham's motivation-indeed this is a close paraphrase of Mipham's commentary on Madhyamakāvatāra-and asserts with perfect clarity Mipham's intuition: there must be a "quality of consciousness qua consciousness" — something that makes awareness awareness. Reflexivity is the characteristic he identifies-the characteristic through which consciousness exists as consciousness. He continues to follow what might be a formula for a Svātantrika position as that school is characterized by dGe lugs doxography. That is, this existence of consciousness through its own characteristics is not, pace the Cittamātra, an ultimate fact, but is merely conventional: 
The validation urged by Mipham ... must be the result of an investigation which is of the conventional transactional type. In other words, svasamvedana exists conventionally, but not ultimately. (p. 148)

Finally, let us note a direct connection that William sees between this debate and debates in modern and postmodern Western philosophy. He sees that Mipham is endorsing a Cartesian view of self-knowledge and of the nature of awareness. Given Tsong khapa's profoundly anti-Cartesian intuitions (if I can be permitted a cross-cultural anachronism), it is not surprising that he takes issue with the view that Mipham was to defend. It is not the case that Tsong khapa simply did not see this issue. It was front and center in his mind, and his view is arguably much subtler than either Mipham's or Williams':

Indubitability upon manifestation - the indubitability of the contents of one's own consciousness qua contents of one's own consciousness-is, for Mipham, a quality which invariably and equally accompanies all consciousness in the very occurrence of a consciousness, as implicated in the actual nature of consciousness itself.... For Mipham this is self-evidently how it is, and if reflexivity is understood in this way then whoever says there is no such thing can only be wondered at with an incredulous shake of the head. To deny such reflexivity is patently false. It is, for Mipham, like a person who is holding onto something very tightly and yet denies she is carrying anything at all. We might add that we are very close here to a version of the Cartesian cogito. Mipham seems to want to say that [the] dGe lugs opponent's position is more than just absurd, it is also contradictory. I cannot consistently wonder or be unsure whether I am conscious or not. (pp. 148-149)

The Cartesian themes continue. Williams notes that Mipham invokes the phenomenon of the veridical self-presentation of the contents of consciousness as an explanandum demanding the reflexivity of awareness. He argues that since the mind is veridically and immediately present to itself as an object of knowledge, awareness must be reflexive:

Supposing one's own mind were an object hidden from oneself. In that case it could be known only through an inference. But such an inference would be impossible. Take the case of the inference, 'I have a consciousness, because I apprehend a strawberry'. First, Mipham wants to say, there could be no possibility of the logical sign (rtags) 'because I apprehend a strawberry'. The consciousness directly perceiving that the conceptualized cognition of what occurred in one's own mind was or was not like this or that, is under the circumstances of one's own mind being an object hidden from oneself simply not possible. In other words, even if hypothetically a direct perception of a strawberry did occur, since we do not know at the very same time that there has been any perception at all, how could there be the conceptualization or constructing activity which is necessary to everyday perceptual and conceptual discourse? We could never have the conceptualized cognition 'I apprehend a strawberry', and it is difficult to see how there can be an inference of one's own mind when there can be no logical sign on which to base the inference.... If one's own mind is an object hidden from oneself and is therefore not directly perceived then, with the failure of inference, by what could it be ascertained by oneself? (pp. 173-174) 
So, Williams maintains, and I agree, that we have in Mipham's defense of the reflexivity of consciousness an appeal to self-evidence, an appeal to privileged access, an appeal to the immediacy and veridicality of self-awareness, and an appeal to the necessity of a criterion for distinguishing the sentient from the non-sentient. Mipham claims not only that this is the right way to understand the nature of consciousness, but also that this is the correct way to understand Indian Prāsangika-madhyamaka theory as articulated by Candrakīrti and Sāntideva.

\section{Why Williams Thinks He Is Right and What Williams Thinks Is at Stake}

There is a lot of hermeneutical action in this discussion. We are considering not only the competing interpretations of Indian sources by two Tibetan exegetes (all as interpreted by me, of course), but also Paul Williams' interpretations both of the Indian sources and of the competing Tibetan interpretations (again, as interpreted by me, of course). Let us now turn to Williams' defense of Mipham's hermeneutical and philosophical strategy. Williams begins by arguing that Mipham is perfectly correct to reject as inadmissible for any prāsanigika-mādhyamika any discussion of the conventional status of reflexive awareness, as its conventional status is irrelevant to Cittamātra, and as no prāsañgika should even care what exists conventionally, since prāsangika analysis is always directed to the question of ultimate, or inherent existence. The conclusion that there is no reflexive awareness ultimately, he argues, should be the end of the matter, and represents the correct interpretation of Madhyamakāvatāra:

[I]t seems to me that Mipham, operating within the framework supplied by his commentary to Sanntideva, is right in asking why it is that his opponent is so concerned with whether or not the ālaya-vijñanna and svasamvedana exist conventionally. Prima facie it does not seem that these two doctrinal categories need necessarily involve inherent existence, even if their discussion does arise within the context of a consideration of Cittamātra. For Mipham it is precisely because-within this context of a discussion of Cittamātra-the substratum-consciousness and self-awareness are urged as inherently existent in order to support the Cittamātra perspective or an inherently existent nondual consciousness stream, that they are opposed by the Mãdhyamika at all. (p. 184)

Williams then offers a list of what he takes to be the four principal reasons why dGe lugs scholars reject the reflexivity of awareness conventionally, and demonstrates that each is a bad reason:

(1) For consciousness to be reflexively aware it must be inherently existent; there can be no conventional svasamvedana. (pp. 186-187)

In this view, according to Williams, the objection to reflexive awareness is that, for awareness to be reflexive, awareness would validate its own nature, and hence would be independent, and hence inherently existent. Since nothing is inherently existent, there can be no reflexive awareness. Now we must agree with Williams that this would be a terrible argument. Though I do not agree that there is any evi- 
dence that Tsong khapa ever offers it, this is indeed an argument that crops up in discussion with dGe lugs scholars with disturbing regularity. Here is Thupten Jinpa:

Tsong khapa's central objection is that positing such a faculty is tantamount to resurrecting the ghost of svabhāva, i.e., intrinsic being, which he has vehemently argued against. In the final analysis, svasamvedana remains another metaphysical postulate whose purpose is to provide a firm grounding for a substantially real world of consciousness. This, according to Tsong khapa, is nothing but an attempt to absolutize consciousness. (Jinpa 2002, p. 127)

Blumenthal also attributes this argument to Tsong khapa. Neither supplies any textual source:

Tsong khapa argues that if self-cognizing cognition is dependent only on itself, then it must be self-produced and therefore inherently existent, an obviously unacceptable tenet for any Mādhyamika. (Blumenthal 2004, p. 85)

But, as Williams points out, the fact that a moment of consciousness is reflexive, and hence self-identifying, does not in any way entail that it is independent of causes and conditions, and hence that it is inherently existent:

(2) The refutation always occurs in the context of refutation of Cittamātra; so to endorse svasamvedana is to endorse Cittamātra. (Williams 1998, pp. 188-192)

Once again, though I do not agree that Tsong khapa ever offers this argument, it is nonetheless a recurrent theme in philosophical discussion in the dGe lugs tradition, and it is a terrible argument. On the other hand, we must remember that the fact that there are terrible arguments for a position in no way counts against that position, but only against its benighted partisans.

(3) Reflexive awareness is rejected in the dGe lugs tradition because of hostility to the Ris med movement. (pp. 193 ff.)

Now, since the Ris med movement was a phenomenon of late nineteenth- and early twentieth-century Tibetan intellectual life, one can imagine that recent dGe lugs pa scholars hostile to that movement might, out of spite for Mipham, who was indeed among its most prominent advocates, reject his position on reflexive awareness. But here I do think that the attribution is historically tendentious, because (1) there was, by the time of the ascendancy of Ris med, already a well-established dGe lugs hostility toward reflexive awareness grounded in Tsong khapa's and rGyal tshab's attacks, and (2) even dGe lugs scholars sympathetic with Ris med reject the reflexivity of awareness.

The final bad argument Williams attributes to the dGe lugs against the conventional existence of reflexive awareness is this:

(4) A nondual awareness by a Buddha of its own consciousness would be an ultimate truth, but would be a positive phenomenon. (pp. $206 \mathrm{ff}$.)

The idea here is that the only ultimate truth is emptiness, and emptiness, according to Prāsanigika-madhyamaka is a negative phenomenon. But if awareness is reflexive, 
and if a Buddha cognizes the ultimate truth of things, then any cognition by a Buddha would be reflexive, and hence positive, but still ultimate. This is a contradiction, though an ingenious argument. And it is unattested, to my knowledge, in dGe lugs pa scholarship. Nor have I ever run across it in discussion. Still, one can imagine it being offered, and indeed it is, as Williams points out, unsound, in that a Buddha is aware not only of the ultimate truth but also of the conventional.

So, where are we? We have a catalog of bad arguments, at least some of which have been offered by some followers of Tsong khapa, against the reflexivity of awareness. Even if they are bad, and even if they were the principal arguments in the dGe lugs literature against the reflexivity of awareness, this would not count against the doctrine. And, as we have seen, the defense of the doctrine, in the hands of both Mipham and his most prominent Western partisan, may have its own difficulties. So the issue is far from settled. Let us now finally turn to a consideration of what Tsong khapa actually has to say about these issues.

\section{Tsong khapa's Views: A Closer Look}

I would like to begin with a consideration of some important passages from $d B u$ ma dgongs pa rab gsal, Tsong khapa's extensive commentary on the Madhyamakāvatāra and a principal site for his development of his own distinctive account of the Prāsañgika position. The following remarks occur under the outline head, "How, according to our own system, even through there is no reflexive awareness, there is memory" and, within that, under the subsection "How to understand this according to Madhyamakāvatāra-bhāsya":

Suppose someone asked, "If according to your view there is no assertion of reflexive awareness, how does memory occur?" According to mundane convention, the mind does not experience itself. But the previous state of consciousness perceives a previous object, and this is the cause of the effect, which is the later memory. (Tsong khapa 1988, p. 289)

Tsong khapa makes two points here: first, if the explanation of memory is the point of positing the reflexivity of awareness, that posit is otiose. For, as Candrakīrti and Śantideva point out, memory can be conceived simply as a causal process; and there is no independent mundane evidence of reflexivity. Tsong khapa next considers and replies to several responses by partisans of reflexivity. He first considers the claim that if there is no reflexivity to awareness, we would never be aware at all, responding that the structure of introspection is as characterized by the distinction between subject and object as is the structure of external perception:

Suppose one thought as follows: Since it would be to deny that one experiences such things as pleasure and pain through the introspective consciousness, how could there be no reflexive awareness? We commit no such error, because the denial of reflexive awareness is consistent with the distinction between subject and object with respect to all cognitive states that are directed inwards.... According to mundane nominal convention as well, the experience of pleasure and pain occurs in this way. Since the perceiver 
and the perceived appear distinctly, there is no need to posit reflexive awareness as per the previous position. (p. 297)

Tsong khapa anticipates that behind the view that awareness must be reflexive is the intuition that if it were not, there would be no awareness at all: how could I be said to be aware of a strawberry if I am not at the same time aware that I am aware of the strawberry? And we don't want to posit the infinite regress of meta-awarenesses anticipated and rejected by Tsong khapa's Indian predecessors. But Tsong khapa cuts off the regress exactly where it should be cut-at the root. I certainly can be aware of the pleasure of a strawberry or the pain in my back without being aware that I am aware of it. Perceptual contact guides my behavior. Full stop. If I am then aware that I am aware, that is a further cognitive state, distinct from the first, and directed upon it. I can keep climbing the hierarchy of meta-awareness as long as I like, but that is only a potential regress, and hence is not vicious. I will get bored at some point with the endless contemplation of my own cognitive states and reach for another strawberry, despite the pain in my back. ${ }^{10}$ The affinities of this reply to Śantideva's treatment of lamp regress should be obvious.

Tsong khapa then takes the proto-Cartesian bull by the horns: he argues that the kind of veridical, immediate privileged access the proponent of reflexivity desires is chimerical. Introspective awareness, he points out, is no less representational than any other kind of perceptual awareness. When we are aware of our own inner states, we are aware of them as states of a particular kind. And, in general, this kind of conceptually characterized perception is mediated and fallible. In that case, mundane introspective consciousness should be taken to be mediated and fallible in the first place, and hence to provide no ground for positing reflexivity.

Moreover, Tsong khapa argues, if we were to establish the authority and the reflexivity of a state of awareness, we would have to do so by considering it as an object, and determining the characteristics by virtue of which it is authoritative. But that would presuppose that we had a grip on the authority of the epistemic state by means of which we grasp it. However, for the proponent of reflexivity, that is the very state in question, and we would end up begging the question. Reflexivity, hence, does not vouchsafe special epistemic authority, but instead undermines ordinary epistemic authority:

If any consciousness to which the object of that consciousness appears were also its own object, that consciousness would appear as a representation. If that consciousness were non-deceptive with respect to that, that mundane non-deceptive consciousness, just by being known as authoritative, would have to be authoritative. In that case, if the apparent object of knowledge [p. 299] were to be established by that consciousness, the subject would already have to have been. (pp. 298-299)

An examination of Tsong khapa's arguments reveals that he sees rather deeply into these issues, and that the reasons for his rejection of the conventional reality of the reflexivity of awareness amount not to a failure to see an obvious Cartesian point, or a confusion of conventional and ultimate analysis. Instead he sees and explicitly rejects the Cartesian implications of the acceptance of even the conventional exis- 
tence of this kind of reflexivity. Let us now conclude by summing up just what is at stake in this argument, an argument that has turned out to be more philosophically interesting than one might have suspected given its dull doxographic frame, and one that turns out to be doxographically more interesting than it might have seemed at first, as well.

\section{What's Really at Stake, and Why Tsong khapa Was Right}

The doctrine of the essential reflexivity of awareness enters Indian Buddhist thought through the Cittamātra school, in order to provide an account of the intentionality of the mental in the absence of external objects. The refutation of the doctrine, therefore, is presented by Candrakīrti and by Śāntideva in the context of the refutation of this philosophical system more generally. It therefore makes a certain amount of sense to see the important doxographic issue to concern Cittamātra, and indeed this has been the way this discussion has been most widely construed by Tibetan and Western exegetes alike. If it is read this way, the focus on the conventional status of reflexivity looks like a silly confusion. We can thank Mipham for having shown us this fact. But the silly confusion is only apparent. We have seen that when we take Sanntarakșita's discussion into account, the doxographic landscape changes, and we see that while for Cittamātra it is the ultimate status of reflexivity that matters, for Svātantrika reflexivity is posited conventionally as the mark of the mental. Given that the refutation of this position is central to Tsong khapa's original formulation of the distinctiveness of Prāsaniika-madhyamaka, attention to the conventional status of reflexivity makes more sense. This attack is part and parcel of Tsong khapa's attack on the project of giving necessary and sufficient conditions for being a kind of thing in general, as well as of his project of establishing a coherent coherentist account of conventional knowledge.

When we initially approach the critical discussion that Mipham and his followers initiate, it appears that Tsong khapa has missed the obvious: that we are aware of our own minds in a special, immediate way, that our access to our own mental states is veridical and entirely distinct in nature from our access to the minds of others, that we cannot even be aware without being aware that we are aware. But when we attend to Tsong khapa's account it is clear that this issue has not been ignored, after all. In his commentary on the Madhyamakāvatāra we have seen that Tsong khapa specifically asserts that our knowledge of our own mental states, like our knowledge of those of others, is mediate and representational and that we are often simply aware, without turning our attention to our own awareness.

Mipham and his followers resuscitate the hoary memory argument from the Indian Cittamātra sources, arguing that we cannot make sense of the memory of a past event without remembering it as experienced, and hence without having experienced it as experienced. But Tsong khapa is correct in accepting Candrakīrti's and Sāntideva's compelling refutations of this argument.

Mipham's real contribution to this discussion is to focus our attention more than Tsong khapa ever did on what is really at stake in this debate, and so to explain why 
the Indian Prāsanigika-madhyamaka philosophers as well as Tsong khapa and his followers care so much about the issue. It forces questions like these: Is the mind an object hidden to itself, or is it self-revealing? Is our knowledge of our own minds of a piece with our knowledge of others'? How do we know that we have minds? Could we be in error about the nature and/or contents of our mental states, or about what we are doing cognitively?

Mipham and Williams plump for the obvious, but false, answers to these hard questions, and take the fact that Tsong khapa disagrees to mean that he just missed the obvious. They take it for granted that the mind is self-revealing; that we know our own minds in a special, direct way; that we cannot be in error about the nature of our own minds or cognitive activity. While this might be common sense, it is all wrong, and Tsong khapa's great genius is that he saw this and so saw the importance of this issue. If we were to have immediate, veridical knowledge of our own minds, that would amount to having, in Tsong khapa's terms, a Buddha's access to the mind-in more familiar terms, to having direct, non-concept- or theory-dependent access to our own cognitive processes. If we were to have a special kind of access to our own mental processes and were to know others' indirectly, this would be to abandon the publicity and conventional character of the concepts through which we know ourselves, and hence to saddle ourselves with an insuperable problem of other minds, and an insuperable problem about how we ever develop these concepts in the first place. If we were always to be correct about our own cognitive activities, in Tsong khapa's terms, meditation and cultivation would be pointless; in our own, cognitive science would be complete. ${ }^{11}$

And in fact, not only do good Buddhist philosophical arguments (as well as comparable arguments due to such Western paṇditas as Acārya Hume, Acārya Kant, Wittgenstein Rinpoche, and Lama Sellars) confirm the correctness of this approach, but the deliverances of empirical cognitive science do as well.

The wealth of recent literature on the acquisition of Theory of Mind shows us conclusively that we are not born knowing that we have minds, let alone what the contents of these minds are or how we process information. Learning these matters is laborious, and crucially involves language learning and social interaction. Our minds become more transparent to us in just the ways and at about just the time that others' minds become available as objects of knowledge, and that involves extensive conceptual mediation (Garfield, Peterson, and Perry 2001). We know through extensive empirical evidence that awareness exceeds introspectibility. And recent work by Jeannerod and Pacherie (2004) has demonstrated convincingly that even mature, competent individuals regularly misattribute intentions to themselves. We know our minds imperfectly, inferentially, through evidence.

These, of course were the "absurd" consequences Mipham draws from Tsong khapa's insistence that, even conventionally, awareness isn't reflexive. Absurd though they might appear, they are correct. It is part of the genius of Tsong khapa that in his concern to develop a cogent account of knowledge as a foundation for Buddhist soteriology, and in his concern for taking the conventional truth seriously as a domain of knowledge, he saw the importance of talking about the nature of the 
mind as we find it in the empirical world. And another part of his genius is that he generally got it right. On the other hand, he was not always clear about what he had accomplished, and we owe a debt of gratitude to Mipham Rinpoche, who was quite probably the first person in the Tibetan tradition to see just what was at stake, despite having come down on the wrong side.

\section{Notes}

Thanks to Dan Arnold and Mario D'Amato for helpful comments on an earlier draft and to Paul Harrison and the other members of the University of Canterbury Sanskrit reading group for useful discussions of the Bodhicāryãvatāra and Prajñākaramati's commentary that illuminated certain arguments and improved translations. I also thank two anonymous reviewers for Philosophy East and West for comments that were helpful in revising this essay.

1 - A note about doxography is in order to forestall confusion. The terms prāsan்gika and svātantrika are recent Sanskrit calques of the Tibetan thal gyur pa and rang gyud pa, respectively. Neither these terms nor the classification of positions and texts that they denote in Tibet are attested to in the Indian Buddhist literature. Indeed, this doxographic schema as we know it, and in particular the way the distinction is drawn in terms of the acceptance of the existence of phenomena through their own characteristics conventionally, is due to Tsong khapa. I am not concerned in this essay with defending or criticizing this approach to Buddhist doxography. But since the debates we are considering here are framed initially as doxographic debates, and since all of the participants in these debates accept Tsong khapa's formulation of the relevant doxography, we will take it for granted here as the frame within which this discussion is set. Those who wish to worry about the framework itself are directed to Dreyfus and McClintock (2003).

2 - The other-dependent (paratantra) is taken as an aspect sometimes of conventional and sometimes of ultimate reality. As Candrakirti understands its role in Yogācāra metaphysics here (an understanding shared by Tsong khapa), when the imagined (parikalpita) is superimposed on the other-dependent it is conventional; when it is emptied of the imagined and perfected (parinispanna) it is ultimate reality. Candrakirti and Tsong khapa therefore take the other-dependent as the ontological and epistemological foundation of Yogācāra.

3 - Prajñākaramati has a very different reading of this argument. His view is that the argument is that since illumination is the removal of darkness and whereas the flame of the lamp can remove the darkness that obscures a pot, since the flame of a lamp is never obscured by darkness, the flame can never illuminate itself. This reading certainly coheres with Nāgārjuna's mobilization of this example in Mülamadhyamakakārikā VII:9, and with the commentaries by Buddhapālita, Bhāvaviveka, and Candrakīrti on that use. On the other hand, there 
are reasons to prefer rGyal tshab's reading here. In particular, it creates a coherent line of argument addressing the nature of subjectivity and the appropriateness of the illumination metaphor for subjectivity, and is more continuous with the discussion of intrinsic versus extrinsic properties in the next verse (Oldmeadow 1994, p. 41).

4 - It is important to note here that the example is not meant to provide an example of memory, but an analogy. The bear does not remember being bitten by the rat. But the analogy is nonetheless apt and instructive, and undermines the memory argument. The point is that the rat bite is an instance of an interaction with the environment that causes, without any intentional state being directed on it at the time, a later intentional state directed upon the object that caused it. That is the kind of causal/intentional relation whose possibility is denied in the memory argument. Its possibility demonstrates that such causal chains are possible, and indeed the Prāsanigika account of memory is an instance of a chain with such a structure.

5 - Dan Arnold has pointed out (personal communication) that the Tibetan doxography can be a bit misleading here. In making this point Sañtarakṣita is following Dignāga, who is indeed regarded by Tibetans as a Yogācāra theorist. It is not entirely accurate, however, to regard Dignāga as himself idealist in the same sense that, say, Vasubandhu was.

6 - Blumenthal (2004, pp. 47-48) agrees that Śāntarakṣita defends reflexivity specifically because of his commitment to the nonexistence of external objects, and so the need for cognition to be directed purely on itself: "Śāntarakșita ... [describes] self-cognition as the very quality which defines sentience. That which is conscious must be self-conscious by definition.... The reflexive nature of consciousness avoids any sense of subject-object duality ... between consciousness and its object" (p. 48).

7 - Williams (1998) and Blumenthal (2004, pp. 220-221) each agree that Śāntarakṣita differs from his Yogācāra predecessors in two important ways: (1) he does not think that reflexive awareness exists ultimately, and (2) he takes it as the distinguishing characteristic (conventionally) of consciousness. Blumenthal argues that this distinction is often overlooked by dGe lugs pa commentators. He writes:

There is a danger of conflating distinct interpretations of self-cognizing cognition with blanket refutations which do not distinguish subtle variances in interpretation and presentation. In texts such as Tsong khapa's $d B u$ ma dgongs pa ran gsal, where we find an extensive refutation of the notion of self-cognizing cognition, he is clear that this is a part of his larger refutation of the Yogācāra system. He does not state that his refutation could broadly be applied to all notions of self-cognizing cognition, including that of Śāntarakșita (and Kamalaśila), but that seems to be the presumption among many Geluk adherents today. This is not to say that Gelukpas (including Tsong khapa) would not find Sāntarakșita's acceptance of self-cognizing cognition problematic. It is only to add the 
cautionary note that the arguments against self-cognizing cognition in the works of key writers such as Tsong khapa are not aimed at the specific way Śāntaraksita asserts it. (2004, pp. 221-222)

While I agree that the differences are important and that they are often glossed over, I will argue that in fact Tsong khapa has Sañtarakṣita in mind every bit as much as the orthodox Yogācāras in his refutations, and that this in fact is precisely what Mipham (along with Williams) misses when replying to Tsong khapa on this point.

8 - All translations in this section are from the Padmakara translation group's edition of the text (Mipham 2002).

9 - This view might appear to derive some support as well from Khenchen Kunzang Palden's commentary on the Bodhicaryāvatāra, Byang chub sems dpa'i spyod pa la 'jug pa'i tshig 'grel 'jam byangs bla mra'i zhal lung lung bdud rtsi'l thig pa (A commentary on the Bodhicaryāvatāra: The nectar of Mañjuuśri's speech) or from Minyak Kunzang Sonam's commentary on the Bodhicaryāvatāra, Spyod 'jug shes rab le'u'i spyi don rim par phy ba zab mo rten byung gi de kho na nyid yang gsal sgron me (A presentation of the general gleaning of the Wisdom Chapter of the Bodhicaryāvatāra: A brilliant torch illuminating the reality of profound dependent origination). Each of these late nineteenth-early twentieth-century scholars was associated with Mipham Rinpoche. The former was a Nyingma scholar and a direct disciple of Mipham. The latter was a dGe lugs scholar and a disciple of Patrul Rinpoche, Mipham's teacher. Commenting on the twenty-fifth verse, Khenchen Kunzang Palden writes:

The Mãdhyamikas answer that they have nothing to say about experiences such as sight, hearing and understanding, which, if left unanalyzed and considered simply from the point of view of their mere enjoyment, are undeniable. It is impossible to deny them and there is no need to do so. What, then, are the Mãdhyamikas attacking? Belief in the true existence of things, the cause of suffering. "Things" are understood here as what is cognized validly by sight, hearing or mental activity. (Padmakara translation group 1993, p. 53)

Minyak Kunzang Sonam, commenting on the same verse, writes:

To this, the Mãdhyamikas reply: things seen by the visual consciousness, those heard by the auditory consciousness and those known by mental consciousness-all these subjects and objects that only appear conventionally are not to be negated merely on the relative level. What is to be eliminated through perfect reasoning, we assert, is the assumption of the true existence of things, which is the cause of samsara. The ordinary mind, without critically examining them, naturally assumes that all objects and subjects of seeing, hearing and knowing are objectively existent. It is this assumption that must be rejected. But there is no need to negate phenomena which appear on the relative level only.... Nor would we be able to negate such phenomena because, in order to do so, we would have to refer to scriptures and reasoning, and these, being themselves mere relative appearances, would also become the object of our refutation. (Ibid., p. 160) 
These assertions might be taken as evidence that according to these scholars Mādhyamika arguments are aimed only at the inherent existence of that which exists conventionally. But to read them this way in this context would be to miss the important point that in each of these texts the author refers specifically to the objects of ordinary perceptual awareness and to the faculties by means of which one is aware of them. These are conventionally existent, and are not to be undermined by Madhyamaka argument. Reflexive awareness, on the other hand, is not explicitly mentioned as among the things taken to be conventionally real, though ultimately nonexistent, despite the fact that these commentators are discussing the passages of Bodhicaryāvatāra in which its existence is at issue. Surely, neither of these commentators can be taken to mean that just anything a philosopher dreams up is therefore conventionally real. That would be to fly in the face of any reasonable version of Madhyamaka.

10 - See also Jinpa 2002, p. 128, for a similar reading of this argument and of the reply to the memory argument.

11 - Note that none of these points directly concerns either the ultimate status of the reflexivity of awareness or a refutation of Yogācāra. The issues between Tsong khapa and Mipham are, hence, pace Williams, Blumenthal, and Jinpa, epistemological issues concerning the nature of self-knowledge and doxographical issues concerning the relationship between Prāsangika and Svātantrika Madhyamaka.

\section{References}

Blumenthal, J. 2004. The Ornament of the Middle Way: A Study of the Madhyamaka Thought of Śāntarakșita. Ithaca: Snow Lion.

Candrakīrti. 1992. dBu ma la 'jug pa'i bshad pa. Sarnath: Kargyud Relief and Protective Committee.

Dreyfus, G., and S. McClintock, eds. 2003. The Svātantrika-Prāsanigika Distinction: What Difference Does a Difference Make? Boston: Wisdom Publications.

Garfield, J. L., C. Peterson, and T. Perry. 2001. "Social Cognition, Language Acquisition and the Theory of Mind." Mind and Language 16:494-541.

rGyal tshab dar ma rin chen. 1999. Byang chub sems pa'i spyod pa la 'jug pa'i rnam bshad rgyal sras jug ngogs. Sarnath: Gelugpa Student Welfare Committee.

Ichigo, M. 1985. Madhyamakālamikāra of Śāntakrakṣita with his own Commentary or Vrtti and with the Subcommentary or Pañjikā or Kamalaśila. Kyoto: Kyoto Sangyo University Press.

Jeannerod, M., and E. Pacherie. 2004. "Agency, Simulation and Self-identification." Mind and Language 19:113-146. 
Jinpa, Thupten. 2002. Self, Reality and Reason in Tibetan Philosophy: Tsong Khapa's Quest for the Middle Way. London: Curzon.

Mipham, Jamgön. 2002. Introduction to the Middle Way: Candrakinti's "Madhyamakāvatāra" with Commentary, translated by Padmakara Translation Group. Boston: Shambala.

Oldmeadow, P. 1994. A Study of the Wisdom Chapter of the Bodhicāryāvatārapañjikā of Prajñākaramati. Ph.D. Dissertation, Australian National University, Canberra.

Padmakara Translation Group. 1993. Wisdom: Two Buddhist Commentaries on the Ninth Chapter of Sāntideva's "Bodhicaryāvatāra." Peyzac-le-Moustier: Editions Padmakara.

Tsong khapa. 1988. bBu ma dgongs pa rab gsal. Sarnath: Gelugpa Student Welfare Committee.

Williams, P. 1983. "On Rang Rig." In E. Steinkellner and H. Tauscher, eds., Contributions on Tibetan and Buddhist Religion and Philosophy: Proceedings of the Cosma de Körös Symposium, 1981, vol. 2, pp. 321-332. Wien: Arbeitkreis für Tibetische und Buddhistische Studien Universität Wien. Reprinted in Williams 1998, pp. 232-246.

1998. The Reflexive Nature of Awareness: A Tibetan Madhyamaka Defence. London: Curzon. 